\title{
Carbon Balance of Grasslands on the Qinghai-Tibet Plateau under Future Climate Change: A Review
}

\author{
Rong Leng ${ }^{1,2}$, Quanzhi Yuan ${ }^{1,2, *}$, Yushuang Wang ${ }^{1,2}$, Qian Kuang ${ }^{1,2}$ and Ping Ren ${ }^{1,2}$ \\ 1 Key Lab of Land Resources Evaluation and Monitoring in Southwest, Ministry of Education, \\ Sichuan Normal University, Chengdu 610066, China; 20181101005@stu.sicnu.edu.cn (R.L.); \\ 20181101002@stu.sicnu.edu.cn (Y.W.); 20171103004@stu.sicnu.deu.cn (Q.K.); renping@sicnu.edu.cn (P.R.) \\ 2 Institute of Geography and Resources Science, Sichuan Normal University, Chengdu 610101, China \\ * Correspondence: yuanqz@sicnu.edu.cn
}

Received: 29 November 2019; Accepted: 8 January 2020; Published: 10 January 2020

check for updates

\begin{abstract}
Climate change has brought significant impacts upon the natural ecological environment and human social development. The future carbon balance study has become an important part of research on the impacts of climate change. The Qinghai-Tibet Plateau (QTP) is a key area for studying climate change. Grassland, as a typical ecosystem of the QTP, embodies the sensitivity of the plateau to the climatic environment, so the carbon balance of grassland under future climate change conditions is important for studying global change. This paper reviewed the literature on carbon balance projection of grassland on the QTP under climate change. Two types of research methods were used to analyze and discuss the studies' results, including experimental scenario projection and model projection. The experiment projected that appropriate temperature and moisture could enhance the carbon sink capacity of a grassland ecosystem, where moisture played a leading role. The model projection results showed that the carbon balance under different spatial and temporal scales were different. Although both can project the carbon balance of the study area, there are still some uncertainties. In addition, this research area should also consider the influence of human activity and plateau pikas to more accurately project the future carbon balance.
\end{abstract}

Keywords: climate change; future; carbon balance; Qinghai-Tibet Plateau (QTP); grassland; projection

\section{Introduction}

Climate change is the main issue facing the current ecological environment. An Intergovernmental Panel on Climate Change (IPCC) report states that climate change is an urgent and potentially irreversible threat to human society and the planet [1]. For example, the drought caused by climate change has led to a decrease in photosynthesis in the Amazon forest, which has reduced the total absorption of $\mathrm{CO}_{2}$ by forests [2]. Similarly, drought increases the vulnerability of older forests, and only low bushes may continue to survive, which will change the global carbon cycle [3]. Due to climate warming, the spread of viruses and the possibility of infection will increase, bringing more disease risks to the ecosystem [4]. More seriously, climate change may bring the extinction of certain species and affect biodiversity [5]. However, climate change will also have a positive impact on different ecosystems. For example, because low temperature limits the growth of vegetation in high latitudes and the Qinghai-Tibet Plateau (QTP), climate warming promotes the growth of vegetation in these areas to a certain extent, and climate change has increased the global leaf area index (LAI), which has resulted in a greening trend range exceeding $28.4 \%$ of the global vegetation area [6]. In short, climate change affects the sustainable development of global ecosystems and human society, and as such, increasingly more people are paying attention to this issue. 
The carbon balance affects climate change to some extent [7], which has been an important part of the study on climate change [8-12]. The study of the future carbon balance is gradually becoming the focus of scientists, who hope to accurately project the future carbon balance and provide a scientific basis for warnings regarding future climate and environmental changes in advance. The IPCC Special Report on Emissions Scenarios (SRES) provided four scenarios (A1B, A2, B1, and B2). These were:

- A1B: Assume that the world's population has stabilized, high tech is widely used, global cooperation takes place, there is rapid economic development, and there is a balance between various energy sources.

- A2: Assume there is self-reliance, maintenance of local characteristics, continuous population growth, slow development of new technologies, economic development is mainly oriented to the region, and the per capita economic growth rate is lower than that of other scenarios.

- B1: Assume there is high economic growth, low population growth, and sustained globalization. The economic structure is rapidly adjusting to the service and information economy. It emphasizes global solutions for sustainable economic, social, and environmental development, including the improvement of fairness.

- B2: Emphasize local solutions for economic, social, and environmentally sustainable development. Population and economic growth are modest, and the pace of technological change is slower and more diverse than in the B1 and A1B scenarios. Although the scenario is also committed to environmental protection and social equity, the focus is on the local and regional levels [13-15].

Studies have used these scenarios to project the carbon emissions in 2030 and 2050. The results showed that, compared with 1996, global black carbon emissions in 2030 and 2050 would decrease by $0.7-2.7 \mathrm{Tg}\left(1 \mathrm{Tg}=1 \times 10^{12} \mathrm{~g}\right)$ and $1.9-3.7 \mathrm{Tg}$, respectively, and organic carbon emissions would decrease by 4-10 $\mathrm{Tg}$ and 6-13 $\mathrm{Tg}$, respectively [13]. Le Quere et al. produced a global carbon budget from different sources of $\mathrm{CO}_{2}$, including the fossil fuel industry, land use change, oceans, land, and atmosphere [16-20]. The results obtained for different regions, different budgets, and prediction methods were less consistent. Therefore, it is not easy to project carbon balance, which requires us to constantly do this work to keep abreast of the global carbon cycle and improve our ability to project carbon in the future [21].

According to previous research by scientists, the research on carbon balance problems is full of challenges and uncertainties. Different ecosystems in the global environment have different carbon cycle and carbon balance processes. When we are considering the projection of a future carbon, it should be based on a concrete analysis of a specific area and ecological system such that a projection for the global carbon balance is not an objective for each area. The QTP is an ideal area for climate change research because it has an average altitude of more than $4000 \mathrm{~m}$ and an area of about $2.5 \times 10^{6} \mathrm{~km}^{2}$, making it the highest and largest plateau in the world [22]. The special geographical environment makes it very sensitive to global climate change $[23,24]$; as such, the QTP plays a very important role in global climate change research [25]. Grassland is the main ecosystem in the QTP [26,27], which accounts for $44 \%$ of China's grassland area [28], and it plays a vital role in regulating the ecological function of the QTP [29]. In addition, the frozen soil environment is closely related to the grassland in the QTP [30,31], and because permafrost is a large carbon pool [32], as part of the QTP grassland ecosystem, its changes have a significant impact on the grassland carbon balance. Coupled with the high sensitivity of high-altitude ecosystems to environmental changes [33], these make the grassland ecosystem a typical environment for exploring the relationship between climate change and ecosystems on the QTP. The study of the grassland ecosystem on the QTP can help people to project the future carbon balance under climate change [34]. Therefore, this paper reviewed the carbon balance research and trend projection of grassland in the QTP that has taken place in recent years. We have cited a total of 132 references, including 8 before 2000, 32 from 2000-2010, and 92 from 2010 and later. The reference period we mainly considered was 2010-2019. One of these references was proceedings (UNFCCC), 
while others were peer-reviewed journal articles. By reviewing this literature, we explain and discuss the latest research and provide a scientific basis for global climate change research.

\section{Trend of Climate Warming and Humidification and the Degradation of Frozen Soil of the Qinghai-Tibet Plateau}

The temperature in the QTP has risen in recent years [35]. The fifth phase of the Coupled Model Intercomparison Project (CMIP5) provided a multimodel dataset designed to advance our knowledge of climate variability and climate change [36]. Then, it was used to project the climate change of the QTP for the next 94 years (2006-2100). The results showed that the temperature of the QTP would rise continuously, and it would rise by $2.44{ }^{\circ} \mathrm{C}$ from 2006 to 2100 [37]. Dong et al. predicted that the average temperature of the QTP in the next 50 years would be $0.46^{\circ} \mathrm{C}$ higher than that in the last 30 years of the 20th century by using a fuzzy mean generating function model (FMGF) and historical data. Furthermore, compared with the last decade of the 20th century, the average temperature would be $0.18{ }^{\circ} \mathrm{C}$ higher [38]. The 20 climate models used in the Fourth Assessment Report of the Intergovernmental Panel on Climate Change (IPCC-AR4) were used to combine the simulation results of future atmospheric greenhouse gas emission scenarios (A1B) with the Community Climate System Model version 3 (CCSM3) simulation output [39] (the CCSM3, a global coupled climate model, is mainly used for research on climate change, climate scenario simulation, and the stabilization of greenhouse gas concentrations [40]). The results showed that the average annual surface temperature in most areas of the plateau from 2030 to 2049 would increase by $1.4-2.2^{\circ} \mathrm{C}$ from 1980 to 1999 . Although the precipitation rate would increase by no more than $5 \%$ in most areas, on the whole, the climate on the QTP is predicted to change in a warm and humid direction [39]. Based on the two emission scenarios (A2 and B2) provided by the Data Distribution Center (DDC) of the IPCC Third Assessment Report, the average simulation results of the five models were used to analyze the future temperature and precipitation changes on the plateau region and along the railway. Results showed that the plateau would continue to warm in the 21st century in the face of increased greenhouse gas emissions caused by human activities and the temperature of the entire plateau would rise by $2.8-3.0^{\circ} \mathrm{C}$ from $2041-2070$. In general, in the A2 and B2 emission scenarios, most of the precipitation in the first 50 years of the 21st century would increase, and the climate of the QTP would change in the direction of warmth and wetness [41].

Climate changing also enhances the melting trend of frozen soil. To understand the future trend of frozen soil, Lu et al. used a surface frost number model that was combined with projected atmospheric variables under four different representative quantitative concentration pathways (RCP2.6, RCP4.5, RCP6.0, and RCP8.5) to simulate and predict the distribution of frozen soil on the QTP in the short, medium, and long term [42]. Here, representative concentration paths (RCPs) are the scenarios used in the fifth report of the IPCC, which includes RCP2.6, RCP4.5, RCP6.0, and RCP8.5. Among them, RCP2.6 is a scenario in which the global average temperature rise is limited to $2{ }^{\circ} \mathrm{C}, \mathrm{RCP} 4.5$ is a scenario in which the radiative forcing is stabilized at $4.5 \mathrm{~W} \cdot \mathrm{m}^{-2}$ in $2100, \mathrm{RCP} 6.0$ is a scenario in which the radiative forcing is stabilized at $6.0 \mathrm{~W} \cdot \mathrm{m}^{-2}$ in 2100 , and RCP8.5 is the scenario with the highest greenhouse gas emissions [43]. Results from this simulation study of frozen soil degradation showed that the degradation area of permafrost would increase with time, and regarding its performance in the short term (2011-2040), the permafrost degradation area would be the smallest and the data showed that the degradation rate of the permafrost under the paths of RCP2.6, RCP4.5, RCP6.0, and RCP8.5 would be $17.17 \%, 18.07 \%, 12.95 \%$, and $15.66 \%$, respectively; in the medium term (2041-2070), the degradation of frozen soil would be faster; and in the long term (2071-2099), permafrost degradation area would be the largest, among which, the distribution of permafrost simulated in RCP8.5 path would decrease by $64.31 \%$ [42]. Similarly, Ni projected the change of permafrost area on the QTP by using a BIOME3China model, an improved process-based equilibrium terrestrial biosphere model (BIOME3) [44] according to China's ecological process, which projected that the permafrost in the current climate and its response to climate warming by simulating vegetation and net primary productivity (NPP). The projection 
results showed that in the future, under the condition of climate change, the area of permafrost would decrease greatly, but the area of non-permafrost would increase, resulting in the boundary position between the permafrost and non-permafrost would moving to the north by 1-2 degrees in latitude [45]. Therefore, over time, future warming will have a significant impact on the permafrost ecosystem.

Most of the research results on the future climate change of the QTP show a warm and humid future climate [46-52], except that the results in some areas would be warm and dry [53], which would directly affect the change in the carbon balance in the plateau grassland. Studies on the projection of the carbon balance under future climate change would be helpful to understand the future change trend of the ecosystem of the QTP.

\section{Projection of Carbon Balance of Grasslands on the Qinghai-Tibet Plateau}

For the projection of the carbon balance of the grassland ecosystem on the QTP, most of the studies are carried out through the scenarios of future climate change and they mainly use scenario simulation methods, which can be divided into two categories. The first type is experimental scenario projection, which mainly projects the carbon balance by controlling environmental variables, such as measuring carbon emissions under quantitative control scenarios of temperature and moisture, and then projecting carbon balance in future climate change scenarios. The second category is model projection, where first, the model is run and verified through experimental data, historical data, or literature data, and then the future carbon emissions are estimated based on future scenario data and specific algorithms. Although both methods need to be tested, the experimental scenario projection is performed using a set of climatic condition, and the model uses the measured data from a historical period to test the accuracy of the model projection. Therefore, this paper divides the projection of carbon balance of the QTP grassland under future climate change into two parts, namely experiment and model parts, to discuss the future carbon balance of the QTP grassland ecosystem.

\subsection{Experimental Scenario Projections of the Carbon Balance}

The projection of the experiment is based on the temperature and moisture content. However, an increase of temperature will lead to an increase of the grassland ecosystem temperature and a decrease of moisture content. At the same time, moisture content will also have a certain impact on the temperature. Therefore, these two elements are integrated and analyzed. The experimental scenario projection is shown in Table 1.

Net primary productivity (NPP) represents the total amount of organic dry matter produced by plants in a unit time and unit area, and it represents the carbon absorption of vegetation to a certain extent $[54,55]$. Through the open-top chambers (OTCs) experiments in the QTP, Ganjurjav et al. found that both the organic carbon and NPP in alpine meadows increased over three years of warming [56]. However, under the same climate scenario, the organic carbon and NPP of alpine grasslands had a decreasing trend, which was mainly caused by the different water-holding capacity of the two grassland ecosystems. The water-holding capacity of meadow soil was larger than that of grassland soil, so the carbon emissions in the two grassland ecosystems would be different [56]. The eddy covariance measurement results also showed that moderate warming would lead to a weak carbon sink trend in the alpine meadow of the QTP $[57,58]$. This is consistent with the results of three different ecosystem carbon cycles. The researchers conducted three-year experimental studies on the warming of an alpine meadow, alpine grassland, and artificial grassland to observe and analyze the warming response of three grassland ecosystems. The results showed that in the future warming climate, the net carbon intake of an alpine meadow increased, while the net carbon intake of an alpine grassland and artificial grassland decreased, indicating that there might be a carbon source trend in the QTP [59]. Moreover, studies have shown that the reason why the warming time (2 years and 10 years) had no significant impact on the carbon cycle of the QTP alpine meadow was mainly due to the small difference in soil moisture under different warming time periods. The research data showed that the short-term and long-term warming caused the soil moisture to decrease by $2.91 \%$ 
and $2.78 \%$, respectively [60]. However, the alpine meadow ecosystem will not always act as a carbon sink because if the soil moisture becomes too low, resulting in the surface drought state not being able to be alleviated by increased precipitation, the alpine meadow will degenerate into a drier grassland type [61], turning the region from a carbon sink to a carbon source. In conclusion, moisture content is an important factor affecting carbon balance, and when the warming amplitude is small, the sensitivity of the carbon flux to water is more obvious than that of high-level warming [62]. 
Table 1. Literature integration of the experimental scenario for projecting the carbon balance from grassland ecosystems of the Qinghai-Tibet Plateau.

\begin{tabular}{|c|c|c|c|c|c|}
\hline $\begin{array}{l}\text { Whether to Consider } \\
\text { Frozen Soil }\end{array}$ & Experimental Scenario & Main Impact Factor & Specific Situation & Projection Result & References \\
\hline \multirow{7}{*}{$\begin{array}{l}\text { Non-permafrost } \\
\text { environment }\end{array}$} & \multirow{3}{*}{$\mathrm{T}^{1} \uparrow+\mathrm{M}^{2}$ unchanged } & \multirow{3}{*}{ Different grass types } & Alpine meadow & Carbon sink & Ganjurjav et al. [56]; \\
\hline & & & Alpine grassland & Carbon source & $\begin{array}{l}\text { Kato et al. [57]; } \\
\text { Kato et al. [58]; }\end{array}$ \\
\hline & & & Artificial grassland & Carbon source & $\begin{array}{c}\text { Ganjurjav et al. [59]; } \\
\text { Wang et al. [60] }\end{array}$ \\
\hline & \multirow{2}{*}{$\mathrm{T} \uparrow+\mathrm{M}$ uncertain } & Moisture content & $\begin{array}{c}\mathrm{M}>40 \% \text { or } \mathrm{M}<15 \% \\
15 \%<\mathrm{M}<40 \%\end{array}$ & $\begin{array}{l}\text { Carbon source } \\
\text { Carbon sink }\end{array}$ & $\begin{array}{c}\text { Kang et al. [63]; } \\
\text { Xue et al. [61] }\end{array}$ \\
\hline & & Vegetation growth stage & $\begin{array}{l}\text { Early growth stage } \\
\text { Late growth stage }\end{array}$ & $\begin{array}{l}\text { Carbon source } \\
\text { Carbon sink }\end{array}$ & Zhu et al. [64] \\
\hline & \multirow[b]{2}{*}{$\mathrm{T} \uparrow+\mathrm{M} \downarrow$} & Vegetation litter & $\begin{array}{l}\text { Vegetation litter content } \uparrow \\
\text { Vegetation litter content } \downarrow\end{array}$ & $\begin{array}{l}\text { Carbon balance } \\
\text { Carbon source }\end{array}$ & Guan et al. [65]; \\
\hline & & $\mathrm{CH}_{4}$ emissions & $\mathrm{CH}_{4}$ emissions $\downarrow<\mathrm{CO}_{2}$ emissions $\uparrow$ & Carbon source & $\begin{array}{l}\text { Li et al. [66]; } \\
\text { Cui et al. [67]; } \\
\text { Kang et al. [63] }\end{array}$ \\
\hline \multirow{2}{*}{$\begin{array}{l}\text { Permafrost } \\
\text { environment }\end{array}$} & \multirow{2}{*}{$\mathrm{T} \uparrow+\mathrm{M} \uparrow$} & \multirow{2}{*}{ Soil respiration } & Soil respiration $\uparrow>$ Vegetation carbon storage $\uparrow$ & Carbon source & $\begin{array}{l}\text { Xue et al. [61]; } \\
\text { Mccarthy [68]; }\end{array}$ \\
\hline & & & Soil respiration $\uparrow<$ Vegetation carbon storage $\uparrow$ & Carbon sink & $\begin{array}{l}\text { Peng et al. [69]; } \\
\text { Peng et al. [70] }\end{array}$ \\
\hline
\end{tabular}

${ }^{1} \mathrm{~T}$ : Temperature, ${ }^{2} \mathrm{M}$ : Moisture content. 
Some experiments have shown that the impact of climate warming on the carbon balance of an alpine meadow was not significant, which may be due to the increase of carbon emission caused by climate warming, but at the same time, the residue of vegetation litter would increase the carbon absorption of the meadow soil such that the two balanced the carbon emission [65]. This may also be due to the fact that the experimental temperature raised the soil temperature, but also brought about a soil moisture loss, resulting in no significant changes in the primary productivity and aboveground biomass of the alpine meadow on the QTP [71]. Furthermore, it may be that warming will have opposite effects on autotrophic respiration and heterotrophic respiration of the ecosystem. When autotrophic respiration is strengthened, heterotrophic respiration is weakened [72], such that carbon emission is not obvious, or it may be that warming inhibits carbon absorption by vegetation in the early growth stage but promotes carbon absorption in the late growth stage [64] such that the effect of warming on carbon balance is not significant. However, there are still differences between autotrophic and heterotrophic respiration in warm conditions. Culture experiments have shown that warming would increase the heterotrophic respiration [73]. Therefore, further research and discussion are needed on this issue.

Water is an important factor affecting $\mathrm{CH}_{4}$ emissions, and drying experiments have shown that lower soil water content could result in lower $\mathrm{CH}_{4}$ emissions [66]. Moreover, studies on vegetation with different degrees of degradation (healthy vegetation, mild degradation, moderate degradation, and severe degradation) also showed that ecosystem respiration was mainly affected by temperature, while $\mathrm{CH}_{4}$ variation was mainly determined by water content [74]. Nevertheless, experiments on moisture restoration in degraded peatlands showed that while increased water content led to increased $\mathrm{CH}_{4}$ emissions, $\mathrm{CO}_{2}$ emissions were reduced, resulting in a total carbon emission reduction of more than $40 \%$ [67], resulting in a carbon sink trend in the plateau. Therefore, the future carbon balance of the QTP grassland may depend on the influence of water on $\mathrm{CO}_{2}$ and $\mathrm{CH}_{4}$ under certain conditions.

In addition, extreme climate is a special case in the process of climate change, and the impact of extreme climate is increasingly significant [75], including the impact on the carbon balance of terrestrial ecosystems [76]; therefore, extreme climate is also considered in this review. In recent years, extreme weather events have occurred frequently, and the large changes in temperature and humidity caused by extreme weather have also affected the carbon balance to some extent [77]. As a climate indicator, the QTP has a certain response [78]. The extreme drying experiment in the field quantified the effect of soil moisture content on carbon balance. The experimental results showed that when the soil moisture was less than $15 \%$ or more than $40 \%$, the carbon dioxide absorption rate was lower, and when the soil moisture content was 20-40\%, the carbon dioxide absorption rate would increase and $\mathrm{CH}_{4}$ emission was strong, but the overall impact on $\mathrm{CO}_{2}$ was stronger. Therefore, extreme dry weather in the future may make the plateau a carbon source [63]. However, extreme weather is generally a short-term weather situation. The driving effect of the carbon balance is a long-term process; therefore, the impact of extreme weather on carbon balance needs further study.

The soil organic carbon storage in the permafrost regions of the QTP accounts for more than $50 \%$ of the total organic carbon storage in the plateau [79]. An infrared heater was used to conduct the experiment in the meadow $\left(92^{\circ} 55^{\prime} \mathrm{E}, 34^{\circ} 49^{\prime} \mathrm{N}\right)$ in the frozen soil area. The experiment showed that the water content of the surface soil $(0-10 \mathrm{~cm})$ decreased, the water content of the deep soil $(20-100 \mathrm{~cm})$ increased, and the water content of the soil layer $(10-20 \mathrm{~cm})$ remained stable. In this case, plants spread their roots deeper into the soil, increasing soil autotrophy and promoting carbon emissions [61], combined with deep soil organic carbon content accounting for more than two-thirds of the entire soil layer [68], which meant permafrost displayed a carbon source trend. Soil warming experiments (2010-2011) with infrared heaters in a similar area $\left(92^{\circ} 56^{\prime} \mathrm{E}, 34^{\circ} 49^{\prime} \mathrm{N}\right)$ also showed that the temperature increase promoted soil respiration and increased carbon emissions. Nevertheless, the depth range of the soil moisture that was affected was different from the previous experiment, in which the 0-20 cm soil moisture decreased and the 40-100 cm soil moisture increased. In addition, increased soil respiration may be due to soil carbon being more easily broken down when thawed [69]. 
However, some soil culture experiments showed that the main factor that increased carbon emission in frozen soil was temperature rise, and the relationship between carbon emission and soil depth was not obvious. Therefore, future warming would lead to an increase in carbon emissions from the entire soil layer [80]. On the contrary, the same infrared heating experiment on frozen soil predicted that the plateau frozen soil would become a carbon sink in the future because the gross ecosystem production (GEP) brought by warming was higher than that of the ecosystem respiration (ER) [70].

Therefore, most of the experimental projections showed that the water brought by climate change was an important factor in the future carbon balance of grassland ecosystems in the QTP, but its impact on the quality and results is still uncertain. If water is assumed to have a negative impact on carbon emissions, the grassland ecosystem in the QTP may gradually become a carbon source system due to the excessive evaporation caused by future climate warming. However, the effect on carbon emissions is more pronounced when water content is lower, and studies showed that plants were less affected by water as they grow when the soil water content exceeds $22 \%$ [61]. Moreover, when the soil water content is greater than $18.13 \%$, the higher the soil water content, the lower the ecosystem respiration intensity [81]. Therefore, when the water in the ecosystem exceeds a certain threshold, the dominant factor of carbon emission may change. This is consistent with the results of studies on the effects of temperature and precipitation on vegetation growth in the QTP [82]. Furthermore, when the water content is within a certain threshold, a dry climate will make grassland trend toward becoming a carbon source. In the future, the water threshold should be studied and determined such that the future carbon emission trend can be more clearly defined. In addition, although experiments have shown the relationship between temperature, moisture, and soil respiration, the carbon emission trends in permafrost regions have different results, and the inducing factors of respiration are still unclear. Soil erosion can also be another source of future organic carbon loss in frozen soils [79], which are issues that need to be clarified in future research. In addition, the difference in the projection results of some experiments may be related to the inconsistency of the spatio-temporal range of the test plots. Future experimental projection studies are needed to enhance the accuracy of the control of spatio-temporal variables.

\subsection{Model-Based Projections of the Carbon Balance}

The use of models to simulate and project the carbon balance has become an important means of studying the development and changes of ecosystems [83,84]. In the future work of carbon balance projecting, it is necessary to determine the research scale, simulation focus, parameter setting, data accuracy, and so on of the model such that the state of model research is continuously improving and developing. There are different regions using different models for carbon balance simulation studies [85-88] and the QTP is an important global ecosystem research area, where research using the model to project the regional carbon balance is gradually increasing. This paper reviewed the research on carbon balance projection of the grassland ecosystem in QTP. The model projection is shown in Table 2.

A process-based ecosystem model called organizing carbon and hydrology in dynamic ecosystems (ORCHIDEE) projected the carbon balance of alpine grassland in the QTP. The results showed that when the temperature increased by $2{ }^{\circ} \mathrm{C}$, although NPP increased by $9 \%$, soil organic carbon decreased by $10 \%$, such that the grassland ecosystem showed a trend toward becoming a carbon source [28]. However, this model lacks certain considerations, such as the erosion of soil organic carbon.

Through the combination of a field experiment and the Carnegie-Ames-Stanford approach (CASA) model, which mainly uses land satellite observations and climate drivers to simulate patterns of regulation of plant production [89], the carbon content of the alpine grassland ecological region on the QTP was estimated to display a net absorption by the atmosphere every year, i.e., the net ecosystem productivity (NEP) was $1.25 \times 10^{13} \mathrm{~g}$ of carbon [90]. Zhou et al. also used the CASA model to study the carbon source/sink nature of the QTP grassland. According to the estimates of the NPP and NEP, they finally concluded that the average NEP over many years in the study area was $1.82 \times 10^{14} \mathrm{~g} \mathrm{C} / \mathrm{a}$, which 
means that the study area on the QTP showed a state of being a carbon sink as a whole [91]. NEP is the difference between the net primary productivity of vegetation and the soil microbial respiration carbon emission in the ecological zone. The calculated NEP is an important indicator for estimating the carbon balance in the region. If the NEP is positive, it means that the fixed carbon in the vegetation is more than the carbon in the soil, which is expressed as a carbon sink. If the value is negative, the carbon emitted by the soil is more than the fixed amount of carbon in the vegetation, which acts as a carbon source [90]. However, there are some problems in using NEP to project a carbon sink state. For example, NEP estimates carbon emissions without taking into account the loss of carbon dioxide from non-respiratory factors, such as soil erosion and grazing and harvesting [92]; as such, it is not completely accurate to only consider NEP as the basis for carbon balance projection.

The coupling model of Biome-BGC (a model developed based on the forest biogeochemical cycles (Forest-BGC) that simulates ecosystem processes $[93,94]$ ) and the simultaneous heat and water (SHAW) model were used when considering the QTP to project the interaction between the alpine meadow ecosystem and the atmosphere. The model selects the net ecosystem exchange (NEE) as a quantitative reference index to project carbon emissions and determines NEE through the relationship among gross primary productivity (GPP), ecosystem respiration (ER), and net ecosystem exchange (NEE), and determines the future carbon emissions. The NEE of this study was $152.6 \mathrm{~g} \mathrm{C} / \mathrm{m}^{2} / \mathrm{a}$, indicating a trend of carbon sequestration in the future. The coupling of the two models made up for the deficiency of the single model and provided a reference for the future study of carbon balance using the model. However, there were still some uncertainties in the projection, mainly because the accuracy of the coupled model needs to be improved [95].

Based on the single Biome-BGC model, the NPP variation and scenario simulation results in the Wudaoliang area of the QTP showed that although temperature and water had a certain influence on vegetation productivity, the effect of temperature and water combined made the influence more obvious [96]. A simulation study was conducted using four scenarios to evaluate the effects of two factors, i.e., the temperature increased by $2{ }^{\circ} \mathrm{C}$ and the precipitation increased or decreased by $20 \%$ and $40 \%$ (T2W20+, T2W40+, T2W20-, T2W40-). The research results showed that NPP showed an upward trend under the four scenarios, increasing by $24.54 \%, 25.68 \%, 21.79 \%$, and $19.94 \%$, respectively, compared with the normal scenario, and the average annual NPP was $67.94 \mathrm{~g} / \mathrm{m}^{2} / \mathrm{a}$. As NPP is an important part of the carbon cycle, its changes affect the carbon sink/source function of the ecosystem [97]. However, we are not clear about soil respiration in this study [96]; the warm and humid environment may cause a carbon sink in the region in the future.

Based on the Century 4.0 model, the dynamic simulation of soil organic carbon in the alpine meadow ecosystem of the QTP showed that although temperature and moisture had different effects on different soil organic carbon (active, slow and passive), the change of total organic carbon was not obvious because the soil organic carbon over a long time would gradually become stable [98]. This may also be due to the fact that climate change did not reach the threshold of significant change in carbon content because it was found that both temperature and precipitation in the study area showed a fluctuation trend over 45 years and the change range was very small. However, a modified Century 4.5 model was used to study organic carbon in eight major alpine grassland ecosystem sites (Hongyuan (lowland meadow), Shenzha (alpine meadow steppe), Shiqu (alpine meadow), Tuotuohe (alpine steppe), Qingshuihe (alpine meadow), Wudaoliang (alpine steppe), Qumalai (alpine meadow), and Shiquanhe (alpine desert steppe)) on the QTP, and the results showed that soil organic carbon had a significant response to climate change, but the change of organic carbon was still affected by many factors, which made the carbon emission trend uncertain [99]. In addition, although the model considered the grazing factors, the appropriate grazing was taken as a hypothesis and the impact of land use change was neglected, so the model was relatively poor at considering human activities. 
Table 2. Literature integration of the model for projecting carbon balance from grassland ecosystems of the Qinghai-Tibet Plateau (QTP).

\begin{tabular}{|c|c|c|c|c|c|}
\hline Model Name & $\begin{array}{l}\text { Whether to Consider } \\
\text { Frozen Soil }\end{array}$ & Study Site or Area & Project Basis & Projection Result & References \\
\hline 2 ORCHIDEE & \multirow{7}{*}{$\begin{array}{l}\text { Non-permafrost } \\
\text { environment }\end{array}$} & $101^{\circ} 18^{\prime} \mathrm{E}, 37^{\circ} 36^{\prime} \mathrm{N}$ & $10 \%$ carbon loss & Carbon source & Tan et al. [28] \\
\hline${ }^{3}$ CASA & & $2.245 \times 10^{6} \mathrm{~km}^{2}$ & ${ }^{8} \mathrm{NEP} 1.25 \times 10^{13} \mathrm{~g} / \mathrm{a}$ & Carbon sink & Pei et al. [90] \\
\hline CASA & & $1.2 \times 10^{7} \mathrm{~km}^{2}$ & NEP $1.82 \times 10^{14} \mathrm{gC} / \mathrm{a}$ & Carbon sink & Zhou et al. [91] \\
\hline${ }^{4}$ Biome-BGC $+{ }^{5}$ SHAW & & $100^{\circ} 27^{\prime} \mathrm{E}, 38^{\circ} 02^{\prime} \mathrm{N}$ & ${ }^{9} \mathrm{NEE} 152.6 \mathrm{gC} / \mathrm{m}^{2} / \mathrm{a}$ & Carbon sink & Wang et al. [95] \\
\hline Biome-BGC & & $93^{\circ} 5^{\prime} 34^{\prime \prime} \mathrm{E}, 35^{\circ} 13^{\prime} 44^{\prime \prime} \mathrm{N}$ & $\begin{array}{l}{ }^{10} \mathrm{NPP} 67.94 \mathrm{~g} / \mathrm{m}^{2} / \mathrm{a} \\
\text { Soil respiration is unclear }\end{array}$ & Possible carbon sink & Li et al. [96] \\
\hline Century 4.0 & & $\begin{array}{l}101^{\circ} 12^{\prime}-101^{\circ} 23^{\prime} \mathrm{E} \\
37^{\circ} 29^{\prime}-37^{\circ} 45^{\prime} \mathrm{N}\end{array}$ & & No obvious trend & Li et al. [98] \\
\hline Century 4.5 & & 8 sites & & Uncertain & Zhang et al. [99] \\
\hline $\begin{array}{l}{ }^{6} \mathrm{RCP} \text { scenario } \\
\text { regression model }\end{array}$ & \multirow[t]{3}{*}{$\begin{array}{l}\text { Permafrost } \\
\text { environment }\end{array}$} & $\begin{array}{l}73^{\circ} 18^{\prime} 52^{\prime \prime}-104^{\circ} 46^{\prime} 59^{\prime \prime} \mathrm{E}, \\
20^{\circ} 00^{\prime} 12^{\prime \prime}-39^{\circ} 46^{\prime} 59^{\prime \prime} \mathrm{N}\end{array}$ & $\begin{array}{c}\text { Carbon loss } 5.34 \mathrm{Pg} \text { from } \\
2015 \text { to } 2050 \\
\text { Carbon loss } 8.54 \mathrm{Pg} \text { from } \\
2015 \text { to } 2070\end{array}$ & Carbon source & Bosch et al. [100] \\
\hline${ }^{7}$ DOS-TEM & & $\begin{array}{c}\text { The permafrost region } \\
\text { of QTP }\end{array}$ & $\begin{array}{c}\mathrm{T}^{1} \uparrow 1^{\circ} \mathrm{C}, \mathrm{SOC} \downarrow 17 \% \\
\mathrm{~T} \uparrow 2^{\circ} \mathrm{C}, \mathrm{SOC} \downarrow 26 \% \\
\mathrm{~T} \uparrow 3^{\circ} \mathrm{C}, \mathrm{SOC} \downarrow 35 \%\end{array}$ & Carbon source & Yi et al. [101] \\
\hline TEM & & 10 sites & Carbon sink 35.8Tg/a & Carbon sink & Zhuang et al. [102] \\
\hline
\end{tabular}


Four different representative concentration paths (RCPs) were used to project the carbon emissions of permafrost on the QTP. The results showed that the melting of frozen soil would increase soil $\mathrm{CO}_{2}$ emissions, and although $\mathrm{CO}_{2}$ emissions would gradually decrease over time, the overall carbon content would decrease. In terms of carbon storage, the projected carbon content values in 2015, 2050, and 2070 are $68.59 \mathrm{Pg}\left(1 \mathrm{Pg}=1 \times 10^{15} \mathrm{~g}\right), 63.25 \mathrm{Pg}$, and $60.05 \mathrm{Pg}$, respectively [100].

The dynamic organic soil version of the terrestrial ecosystem model (DOS-TEM) was used to project the carbon emission trend of permafrost on the QTP. The results showed that in the future climate warming, the study area may also show a trend toward being a carbon source. Although the net carbon absorption in this area was $4 \mathrm{~g} \mathrm{C} / \mathrm{m}^{2} / \mathrm{a}$, the soil organic carbon (SOC) content would gradually decrease with the increase of temperature [101]. In the future, the net carbon absorption may be negative, therefore the projected result is a trend toward a carbon source.

However, the TEM, which is a model that simulates the effects of carbon and nitrogen cycles on terrestrial ecosystems [103], projected that the frozen soil on the QTP would show a trend toward being a carbon sink due to the future climate change because the growth rate of the net primary productivity was faster than the soil respiration rate. The problem is that the model's projections were based on the entire 20th century and did not take into account recent climate change; as such, the accuracy of the model's parameters needs to be improved [102].

At present, using the model to project the carbon balance of highland grassland ecosystems can better simulate carbon balance processes and future trends, but different model studies have led to predicting different trends in the future carbon balance on the QTP. First, this may have a strong relationship with the research spatial and temporal scales. The model projection was for the grassland ecosystem in a certain region of the QTP, which is not the grassland ecosystem of the whole plateau, and therefore the conclusion of the study is weak. The choice of research time is also different, increasing the inconsistency of the research environment. A second point is also related to the model parameters, data accuracy, and the operation of the model itself. For example, in the case of climate warming, the degradation of frozen soil may affect the characteristics of the soil and hydrology, which in turn affects the growth of vegetation; different soil depth and soil erosion also affect the carbon flux of ecosystems, making the trend of the soil organic carbon emissions more uncertain [79]. Therefore, the projection of the carbon balance from the QTP under future climate change needs to integrate different regions and different time conditions to be able to clarify the carbon emission trends of the entire plateau grassland ecosystem. In the future, when using the model to study the carbon balance of grassland ecosystems, it is necessary to continuously adjust and improve such that the model research is more in line with the actual situation.

\section{Conclusions}

This paper reviewed the research on the carbon balance projection of grassland ecosystems on the QTP under climate change, and mainly integrated and summarized two research methods: experimental scenario projections and model projections. The possible results of this review study can be seen in Table 3. The experimental scenario projections focus more on the use of variable control for qualitative trend studies. Because the future climate change of the Tibetan Plateau is moving toward becoming warm and humid, the carbon balance in the future may be a result of carbon sinks. The research basically showed that the temperature and moisture content were important factors affecting the carbon balance, and moderate temperature and water can enhance the carbon sequestration capacity of the QTP. Therefore, the threshold of the temperature and moisture content suitable for the carbon cycle of the plateau grassland ecosystem is the focus of future research. The model projections were based on quantitative projection research using big data and is an important means to study future changes. The models of CASA, Biome-BGC+SHAW, Biome-BGC, and TEM indicated that the grassland ecosystem in the QTP would trend toward being a carbon sink in the future; the ORCHIDEE, RCP scenario regression model, and DOS-TEM model showed a carbon source trend; the results of the 
Century 4.0 model study showed no obvious carbon source or carbon sink trend; and the Century 4.5 model results were uncertain.

Table 3. Projection of carbon balance of the grassland ecosystem in Qinghai-Tibet Plateau based on literature integration.

\begin{tabular}{|c|c|c|c|c|}
\hline $\begin{array}{l}\text { Future Climate } \\
\text { Change on the } \\
\text { Tibetan Plateau }\end{array}$ & $\begin{array}{l}\text { Estimation } \\
\text { Method }\end{array}$ & $\begin{array}{l}\text { Whether to } \\
\text { Consider Human or } \\
\text { Rodent Activities }\end{array}$ & $\begin{array}{c}\text { Possible } \\
\text { Projected Results }\end{array}$ & Future Research Focus \\
\hline \multirow[t]{2}{*}{$\begin{array}{l}\text { Warming and } \\
\text { humidification } \\
\left(\mathrm{T}^{1} \uparrow+\mathrm{M}^{2} \uparrow\right)\end{array}$} & $\begin{array}{l}\text { Experimental } \\
\text { scenario }\end{array}$ & $\mathrm{NO}$ & Carbon sink & $\begin{array}{c}\text { Determination of } \\
\text { temperature and } \\
\text { moisture thresholds } \\
\text { suitable for the carbon } \\
\text { balance }\end{array}$ \\
\hline & Model & $\mathrm{NO}$ & $\begin{array}{l}\text { Determined by the } \\
\text { projected space-time } \\
\text { range and parameter } \\
\text { settings of the model }\end{array}$ & $\begin{array}{l}\text { Research on models } \\
\text { more suitable for the } \\
\text { grassland ecosystem in } \\
\text { Qinghai-Tibet Plateau }\end{array}$ \\
\hline
\end{tabular}

${ }^{1}$ T: Temperature; ${ }^{2}$ M: Moisture content.

Whether it is experimental scenario projection or model projection research, the results between projections are different. For experimental scenario projections, the results may be different due to different factors, such as the time and space of the test; the degree of variable control; and the technical operation, including the time and place of the study, and the control of temperature and moisture; and whether the differences in ecosystems are considered (soil texture, vegetation type, etc.), human factors, rodents, etc. For model projection studies, the results may differ due to factors such as the research scale, spatial distribution, data accuracy, and parameter considerations. For example, whether a global ecosystem scale model can be used to study a region of the QTP, whether the model is running, or whether the model data is accurate. Most of the projection methods from both projection types are limited to a certain area of the QTP, and the projection of carbon balance of the plateau grassland is the direction of future research.

In addition, the QTP has a complex terrain and diverse climatic conditions [104], which leads to a diverse ecosystem, and different ecological environments have different effects on the carbon balance of the QTP [105]. This paper only reviewed the carbon balance projection of the plateau grassland. Therefore, to study the carbon balance of the whole QTP, it is necessary to consider more comprehensive ecosystem conditions.

\section{Outlook}

The current climate change and human activities have direct interactions, and human activities have always had a significant impact on the Tibetan Plateau ecosystem and local climate. In addition, plateau pika activity is an important factor affecting the carbon balance of the grassland on the QTP. Therefore, future studies should not only combine experiments and model projection methods under climate change, but also take human factors and rodent damage into account to make the projection results more scientific and accurate.

\subsection{The Impact of Human Activities on the Carbon Balance}

Human activities have a direct and indirect impact on carbon balance. A certain amount of carbon dioxide is produced by human production and life, and a higher carbon dioxide level in the air will further warm the climate, increasing the temperature by $0.1{ }^{\circ} \mathrm{C}$ to $1.5^{\circ} \mathrm{C}$ [7]. Most of the above experiments and models do not consider the impact of human activities when projecting the carbon balance. However, the change of land use caused by human activities leads to the change of the ecological environment and local climate [106-108], which in turn affects the terrestrial carbon emissions [109]. Therefore, when projecting the carbon balance projection of grassland ecosystems in 
the QTP under the climate change scenario, the factor of human activity should be added. Current studies of the effects of human activities on the carbon balance on the QTP include grazing and wetland drainage.

\subsubsection{Grazing}

Grazing activities have a certain impact on the carbon balance of terrestrial ecosystems, where different degrees of grazing intensity (light grazing, medium grazing, and heavy grazing) and grazing duration have different impacts on the carbon balance [110,111]. Grazing is a typical form of human activity on the QTP. With the increase of grazing intensity, the aboveground and underground biomass is gradually reduced, and the carbon content of alpine soil also decreases $[112,113]$. This can also be seen in the effects of different grazing management systems (fencing, rest of grazing in growth stages, traditional grazing, and continuous grazing). The higher the grazing intensity is, the lower the carbon content in the soil will be. Conversely, when the grazing intensity is weakened, the carbon content in the soil will gradually recover. The study showed that short-term fallow grazing could restore vegetation growth of slightly degraded alpine meadows. On the one hand, recreational grazing reduces vegetation without being affected by livestock; on the other hand, recreational grazing promotes the growth of perennial vegetation and increases the carbon content of the ecosystem [114].

However, the results of the comparison between grazing and banning grazing contradict the above conclusions. Banning grazing increased soil carbon dioxide emissions and reduced carbon sinks during the growing season of the plateau meadow. This may be affected by the grassland type, sampling period, and experimental treatment [115], but the real reason needs further the study. The Environmental Policy Integrated Climate (EPIC) model's study of changes in soil organic carbon stocks from wetlands between 1980 and 2010 also showed that grazing had a positive impact on carbon storage, probably due to the positive effects of grazing on plant roots [116]. The results of this study are consistent with the results of experiments on the effects of different grazing intensities on carbon [117]. Since grazing may cause the increase of roots and plant residues of grassland, the study showed that the soil carbon accumulation of heavy grazing was $47 \%$ and $27 \%$ higher than that of light grazing and moderate grazing, respectively, which improves the carbon sink function of alpine meadows [118].

The EPIC model also found that people drained wetlands for grazing and converted them into pasture suitable for grazing, thereby reducing the storage of organic carbon. Therefore, if grazing is beneficial to carbon sequestration, then grazing and drainage have an offsetting effect on the carbon cycle [116]. Therefore, the balance between the two is important, and it determines the trend of grassland carbon emissions. Short-term grazing bans (6-8 years) also have no significant impact on the total carbon reserves of alpine grassland ecosystems, but this is only the result of short-term experiments, while the impact of long-term grazing bans on carbon emissions needs further study [111].

Therefore, the impact of grazing on the carbon balance of grassland in the QTP is still controversial. It is not clear at present whether an alpine grassland ecosystem is transformed into carbon source or carbon sink with the increase of grazing intensity. This may be related to the vegetation type, vegetation growth, soil texture, soil moisture, and grazing excreta, as well as human research time, research methods, management measures, etc. In the following studies, more rigorous observations and analysis should be made regarding these factors.

\subsubsection{Wetland Drainage}

A wetland ecosystem plays the role of a carbon sink in the global carbon cycle $[119,120]$. It has an important role in ecological protection [121] and it is affected by the environment, especially the water environment, such as water quality and water quantity. Therefore, the wetland ecosystem will be indirectly affected by hydrology in the future climate change [120]. Although the wetland is a typical ecosystem of the QTP, as mentioned above, in order to develop the animal husbandry economy, people have drained the wetland in the past decades to make it a suitable pasture [122], which also had a certain impact on the carbon balance of the grassland of the QTP. Studies have shown that lower water 
levels reduce the amount of organic carbon stored in peatlands. It is possible that lowering the water level will increase the activity of aerobic microorganisms [67] and affect the physical and chemical properties of peat, which may lead to soil carbon loss and reduce the content of soil organic carbon [123]. For example, the peatland water level caused by human activities has dropped and earthworms are more active in low-water peatlands than in high-water peatlands such that their activities may change the vegetation biomass, soil structure, and temperature, and may promote the aggregation of other invertebrates, thus accelerating soil organic carbon emissions and indirectly reducing soil organic carbon content $[124,125]$. In addition, if the carbon sequestration capacity of soil is to be guaranteed, the carbon accumulation rate of peatlands needs to be studied and determined [126].

However, drainage does not always lead to an increase in carbon emissions. Field experiments lasting 40 months showed that drainage mainly increased $\mathrm{CO}_{2}$ emissions in the growing period, but $\mathrm{CO}_{2}$ emissions in the non-growing period were inhibited, which may be due to temperature changes. Studies have shown that organic carbon emissions and temperature may be exponentially related. In addition, drainage also reduces $\mathrm{CH}_{4}$ emissions [127]. Moreover, $\mathrm{CH}_{4}$ emissions decreased significantly during both the growing and non-growing seasons [125], and the decrease in the non-growing season may also be due to the inhibition of cold frozen soil [128]. Although drainage during the growing season increases $\mathrm{CO}_{2}$ emissions and reduces carbon storage in plateau wetlands, the inhibition of $\mathrm{CH}_{4}$ emissions may increase some carbon storage. Therefore, it is necessary to further determine the mechanisms and quantities of the two greenhouse gas emissions, as well as the different responses of growing and non-growing carbon emissions to climate and human activities [125,127].

Moreover, when water levels fall too low, especially during dry periods, soil organic carbon emissions are suppressed. In fact, organic carbon emissions are the highest when soil moisture is moderate (35-45\%) [127]. This is similar to the above-mentioned effect of changes in the grassland ecosystem water content on carbon emissions caused by climate warming, both of which indicate that too much or too little water content will have different impacts on the ecosystem carbon balance.

Wetland drainage has a certain impact on the carbon balance of the grassland on the QTP. Different research conclusions may be related to different conditions of the research site (organic carbon content and temperature) [127], or other factors. Therefore, follow-up studies need to combine temperature and precipitation to quantitatively determine the impact of drainage on the carbon balance.

In addition to the impact of grazing and wetland drainage on carbon balance, ecological governance is also gradually being carried out on the QTP due to the attention paid to ecological construction, which may balance the negative impact of ecological destruction and have a certain impact on the trend of carbon emissions of the whole grassland on the QTP. In addition, drug collection on the plateau is also one of the causes of grassland desertification. Due to the decrease of biomass, carbon emissions on the plateau will also be affected to some extent. Therefore, human activities have increasingly affected the operation of the ecosystem on the QTP. In the future carbon balance projection research, it is necessary to consider the impact of human activities.

\subsection{The Impact of Plateau Pikas on the Carbon Balance}

The plateau pika is a unique biological species on the QTP, which has a significant impact on the plateau ecosystem. On the one hand, the existence of the plateau pika accelerates the degradation of the plateau grassland, yet on the other hand, it maintains the biodiversity [129], so there are many uncertainties regarding the impact of plateau pika on the carbon balance of the QTP grassland.

The study showed that the organic carbon content of a plateau meadow increased when the disturbance intensity of pika was small. When the degree of disturbance is relatively small, the activity of pika on the plateau increases the soil permeability, thus increasing the soil water holding capacity, and its excretion increases nutrient elements for plant growth, such that plants can grow better and the content of organic carbon in meadow increases [130]. Excreta from plateau pika may also directly increase the soil organic matter content [131]. However, when the soil erosion caused by the plateau pika is more than $10 \mathrm{~cm}$, the soil organic carbon content is significantly reduced. This may be due to 
the changes in soil structure caused by the plateau pika and the increase in the range of exposure of organic carbon to the outside world, resulting in an increase in soil organic carbon emissions [132].

Although the extent and manner of the effects of plateau pika activity on the carbon balance of grassland ecosystems in the QTP are still unclear, the plateau pika activity is one of the factors we should consider when studying and projecting the carbon balance of grassland ecosystems in the QTP. Future research may have to pay more attention to the influence of the plateau pika activities, thus producing more accurate projections of the future of the carbon balance.

Author Contributions: Conceptualization, R.L. and Q.Y.; Writing-original draft preparation, R.L.; Writingreview and editing, Q.Y., Y.W., Q.K., and P.R.; Supervision, Q.Y.; Project administration, P.R. All authors have read and agreed to the published version of the manuscript.

Funding: This research was funded by the Projects of National Natural Science Foundation of China (grant No. 41701100).

Acknowledgments: We thank all researchers whose articles were consulted to develop this review paper. We also thank the editor and reviewers for their detailed evaluation and constructive suggestions on the manuscript.

Conflicts of Interest: The authors declare no conflict of interest.

\section{References}

1. UNFCCC 2015. Paris Agreement-Decision 1/CP.21-Report of the Conference of the Parties on Its Twenty-First Session, held in Paris from 30 November to 13 December 2015 Addendum Part Two: Action Taken by the Conference of the Parties at Its Twenty-First Session Bonn. Available online: http://unfccc.int/ resource/docs/2015/cop21/eng/10a01.pdf (accessed on 29 January 2016).

2. Doughty, C.E.; Metcalfe, D.B.; Girardin, C.A.J.; Amezquita, F.F.; Cabrera, D.G.; Huasco, W.H.; Silva-Espejo, J.E.; Araujo-Murakami, A.; da Costa, M.C.; Rocha, W.; et al. Drought impact on forest carbon dynamics and fluxes in Amazonia. Nature 2015, 519, 78. [CrossRef] [PubMed]

3. McDowell, N.G.; Allen, C.D. Darcy's law predicts widespread forest mortality under climate warming. Nat. Clim. Chang. 2015, 5, 669-672. [CrossRef]

4. Harvell, C.D.; Mitchell, C.E.; Ward, J.R.; Altizer, S.; Dobson, A.P.; Ostfeld, R.S.; Samuel, M.D. Ecology-climate warming and disease risks for terrestrial and marine biota. Science 2002, 296, 2158-2162. [CrossRef]

5. Bellard, C.; Bertelsmeier, C.; Leadley, P.; Thuiller, W.; Courchamp, F. Impacts of climate change on the future of biodiversity. Ecol. Lett. 2012, 15, 365-377. [CrossRef] [PubMed]

6. Zhu, Z.C.; Piao, S.L.; Myneni, R.B.; Huang, M.T.; Zeng, Z.Z.; Canadell, J.G.; Ciais, P.; Sitch, S.; Friedlingstein, P.; Arneth, A.; et al. Greening of the earth and its drivers. Nat. Clim. Chang. 2016, 6, 791-796. [CrossRef]

7. Friedlingstein, P.; Cox, P.; Betts, R.; Bopp, L.; Von Bloh, W.; Brovkin, V.; Cadule, P.; Doney, S.; Eby, M.; Fung, I.; et al. Climate-carbon cycle feedback analysis: Results from the C4MIP model Intercomparison. J. Clim. 2006, 19, 3337-3353. [CrossRef]

8. Raupach, M.R.; Marland, G.; Ciais, P.; Le Quere, C.; Canadell, J.G.; Klepper, G.; Field, C.B. Global and regional drivers of accelerating $\mathrm{CO}_{2}$ emissions. Proc. Natl. Acad. Sci. USA 2007, 104, 10288-10293. [CrossRef]

9. Van der Werf, G.R.; Randerson, J.T.; Giglio, L.; van Leeuwen, T.T.; Chen, Y.; Rogers, B.M.; Mu, M.Q.; van Marle, M.J.E.; Morton, D.C.; Collatz, G.J.; et al. Global fire emissions estimates during 1997-2016. Earth Syst. Sci. Data 2017, 9, 697-720. [CrossRef]

10. Holgerson, M.A.; Raymond, P.A. Large contribution to inland water $\mathrm{CO}_{2}$ and $\mathrm{CH}_{4}$ emissions from very small ponds. Nat. Geosci. 2016, 9, 222. [CrossRef]

11. Bouillon, S.; Borges, A.V.; Castaneda-Moya, E.; Diele, K.; Dittmar, T.; Duke, N.C.; Kristensen, E.; Lee, S.Y.; Marchand, C.; Middelburg, J.J.; et al. Mangrove production and carbon sinks: A revision of global budget estimates. Glob. Biogeochem. Cycles 2008, 22, 1-12. [CrossRef]

12. Schlesinger, W.H.; Andrews, J.A. Soil respiration and the global carbon cycle. Biogeochemistry 2000, 48, 7-20. [CrossRef]

13. Streets, D.G.; Bond, T.C.; Lee, T.; Jang, C. On the future of carbonaceous aerosol emissions. J. Geophys. Res. Atmos. 2004, 109, 1-19. [CrossRef]

14. Qin, D.H.; Chen, Z.L.; Luo, Y.; Ding, Y.H.; Dai, X.S.; Ren, J.W.; Zhai, P.M.; Zhang, X.Y.; Zhao, Z.C.; Zhang, D.E.; et al. Updated understanding of climate change sciences. Adv. Clim. Chang. Res. 2007, 3, 63-73. 
15. Zhang, X.Q.; Peng, L.L.; Lin, Z.H. Progress on the projections of future climate change with various emission scenarios. Adv. Earth Sci. 2008, 23, 174-185.

16. Le Quéré, C.; Peters, G.P.; Andres, R.J.; Andrew, R.M.; Boden, T.A.; Ciais, P.; Friedlingstein, P.; Houghton, R.A.; Marland, G.; Moriarty, R.; et al. Global carbon budget 2013. Earth Syst. Sci. Data 2014, 6, 235-263. [CrossRef]

17. Le Quéré, C.; Moriarty, R.; Andrew, R.M.; Peters, G.P.; Ciais, P.; Friedlingstein, P.; Jones, S.D.; Sitch, S.; Tans, P.; Arneth, A.; et al. Global carbon budget 2014. Earth Syst. Sci. Data 2015, 7, 47-85. [CrossRef]

18. Le Quéré, C.; Moriarty, R.; Andrew, R.M.; Canadell, J.G.; Sitch, S.; Korsbakken, J.I.; Friedlingstein, P.; Peters, G.P.; Andres, R.J.; Boden, T.A.; et al. Global carbon budget 2015. Earth Syst. Sci. Data 2015, 7, 349-396. [CrossRef]

19. Le Quéré, C.; Andrew, R.M.; Canadell, J.G.; Sitch, S.; Korsbakken, J.I.; Peters, G.P.; Manning, A.C.; Boden, T.A.; Tans, P.P.; Houghton, R.A.; et al. Global carbon budget 2016. Earth Syst. Sci. Data 2016, 8, 605-649. [CrossRef]

20. Le Quéré, C.; Andrew, R.M.; Friedlingstein, P.; Sitch, S.; Pongratz, J.; Manning, A.C.; Korsbakken, J.I.; Peters, G.P.; Canadell, J.G.; Jackson, R.B.; et al. Global carbon budget 2017. Earth Syst. Sci. Data 2018, 10, 405-448. [CrossRef]

21. Le Quéré, C.; Andrew, R.M.; Friedlingstein, P.; Sitch, S.; Hauck, J.; Pongratz, J.; Pickers, P.A.; Korsbakken, J.I.; Peters, G.P.; Canadell, J.G.; et al. Global carbon budget 2018. Earth Syst. Sci. Data 2018, 10, 2141-2194. [CrossRef]

22. Kang, S.C.; Xu, Y.W.; You, Q.L.; Flugel, W.A.; Pepin, N.; Yao, T.D. Review of climate and cryospheric change in the Tibetan Plateau. Environ. Res. Lett. 2010, 5, 015101. [CrossRef]

23. Yang, M.X.; Nelson, F.E.; Shiklomanov, N.I.; Guo, D.L.; Wan, G.N. Permafrost degradation and its environmental effects on the Tibetan Plateau: A review of recent research. Earth Sci. Rev. 2010, 103, 31-44. [CrossRef]

24. Sun, H.L.; Zheng, D.; Yao, T.D.; Zhang, Y.L. Protection and construction of the national ecological security shelter zone on Tibetan Plateau. Acta Geogr. Sin. 2012, 67, 3-12.

25. Li, X.; Cheng, G.D.; Jin, H.J.; Kang, E.S.; Che, T.; Jin, R.; Wu, L.Z.; Nan, Z.T.; Wang, J.; Shen, Y.P. Cryospheric change in China. Glob. Planet Chang. 2008, 62, 210-218. [CrossRef]

26. Hu, Z.M.; Yu, G.R.; Fu, Y.L.; Sun, X.M.; Li, Y.N.; Shi, P.L.; Wangw, Y.F.; Zheng, Z.M. Effects of vegetation control on ecosystem water use efficiency within and among four grassland ecosystems in China. Glob. Chang. Biol. 2008, 14, 1609-1619. [CrossRef]

27. Fan, J.W.; Shao, Q.Q.; Liu, J.Y.; Wang, J.B.; Harris, W.; Chen, Z.Q.; Zhong, H.P.; Xu, X.L.; Liu, R.G. Assessment of effects of climate change and grazing activity on grassland yield in the Three Rivers Headwaters Region of Qinghai-Tibet Plateau, China. Environ. Monit. Assess 2010, 170, 571-584. [CrossRef] [PubMed]

28. Tan, K.; Ciais, P.; Piao, S.L.; Wu, X.P.; Tang, Y.H.; Vuichard, N.; Liang, S.; Fang, J.Y. Application of the ORCHIDEE global vegetation model to evaluate biomass and soil carbon stocks of Qinghai-Tibetan grasslands. Glob. Biogeochem. Cycles 2010, 24, 1-12. [CrossRef]

29. Huang, K.; Zhang, Y.J.; Zhu, J.T.; Liu, Y.J.; Zu, J.X.; Zhang, J. The influences of climate change and human activities on vegetation dynamics in the Qinghai-Tibet Plateau. Remote Sens. 2016, 8, 876. [CrossRef]

30. Wang, G.X.; Li, Y.S.; Wu, Q.B.; Wang, Y.B. Impacts of permafrost changes on alpine ecosystem in Qinghai-Tibet Plateau. Sci. China Ser. D Earth Sci. 2006, 49, 1156-1169. [CrossRef]

31. Hu, G.J.; Zhao, L.; Wu, X.D.; Li, R.; Wu, T.H.; Xie, C.W.; Pang, Q.Q.; Xiao, Y.; Li, W.P.; Qiao, Y.P.; et al. Modeling permafrost properties in the Qinghai-Xizang (Tibet) Plateau. Sci. China Earth Sci. 2015, 58, 2309-2326. [CrossRef]

32. Zimov, S.A.; Schuur, E.A.G.; Chapin, F.S. Permafrost and the global carbon budget. Science 2006, 312, 1612-1613. [CrossRef] [PubMed]

33. Wookey, P.A.; Aerts, R.; Bardgett, R.D.; Baptist, F.; Brathen, K.A.; Cornelissen, J.H.C.; Gough, L.; Hartley, I.P.; Hopkins, D.W.; Lavorel, S.; et al. Ecosystem feedbacks and cascade processes: Understanding their role in the responses of arctic and alpine ecosystems to environmental change. Glob. Chang. Biol. 2009, 15, 1153-1172. [CrossRef]

34. Kato, T.; Tang, Y.H.; Gu, S.; Cui, X.Y.; Hirota, M.; Du, M.Y.; Li, Y.N.; Zhao, Z.Q.; Oikawa, T. Carbon dioxide exchange between the atmosphere and an alpine meadow ecosystem on the Qinghai-Tibetan Plateau, China. Agric. For. Meteorol. 2004, 124, 121-134. [CrossRef]

35. Song, C.; Pei, T.; Zhou, C.H. Research progresses of surface temperature characteristic change over Tibetan Plateau since 1960. Prog. Geogr. 2012, 31, 1503-1509. 
36. Taylor, K.E.; Stouffer, R.J.; Meehl, G.A. An overview of CMIP5 and the experiment design. Bull. Am. Meteorol. Soc. 2012, 93, 485-498. [CrossRef]

37. Luosang, Q.J.; Bai, M.; Ciren, Q.Z.; Dunyu, D.J.; Mima, L.J.; Nima. Long-term change of temperature on Tibetan plateau based on CMIP5 climate model. J. Tibet Univ. Nat. Sci. Ed. 2016, 31, 52-62.

38. Dong, A.X.; Li, D.L.; Gong, J.F.; Zhang, K. Climatic forecast over Qinghai-Xizang Plateau made using fussy mean generating function (FMGF) model. Plateau Meteorol. 2003, 22, 499-502.

39. Liu, X.D.; Cheng, Z.G.; Zhang, R. The A1B scenario projection for climate change over the Tibetan Plateau in the next 30-50 years. Plateau Meteorol. 2009, 28, 475-484.

40. Meehl, G.A.; Washington, W.M.; Santer, B.D.; Collins, W.D.; Arblaster, J.M.; Hu, A.X.; Lawrence, D.M.; Teng, H.Y.; Buja, L.E.; Strand, W.G. Climate change projections for the twenty-first century and climate change commitment in the CCSM3. J. Clim. 2006, 19, 2597-2616. [CrossRef]

41. Xu, Y.; Zhao, Z.C.; Li, D.L. The simulated result analyses on climate changes over Qinghai-Xizang Plateau and along the railway in the coming 50 years. Plateau Meteorol. 2005, 24, 700-707.

42. Lu, Q.; Zhao, D.S.; Wu, S.H. Simulated responses of permafrost distribution to climate change on the Qinghai-Tibet Plateau. Sci. Rep. 2017, 7, 3845. [CrossRef] [PubMed]

43. Shen, Y.P.; Wang, G.Y. Key findings and assessment results of IPCC WGI fifth assessment report. J. Glaciol. Geocryol. 2013, 35, 1068-1076.

44. Haxeltine, A.; Prentice, I.C. BIOME3: An equilibrium terrestrial biosphere model based on ecophysiological constraints, resourceavailability, and competition among plant functional types. Glob. Biogeochem. Cycles 1996, 10, 693-709. [CrossRef]

45. Ni, J. A simulation of biomes on the Tibetan Plateau and their responses to global climate change. Mt. Res. Dev. 2000, 20, 80-89. [CrossRef]

46. Cheng, Z.G.; Liu, X.D.; Fan, G.Z.; Bai, A.J.; Wang, B.Y. Spatiotemporal distribution of climate change over the Qinghai-Tibetan Plateau in 21st Century. Arid Zone Res. 2011, 28, 669-676.

47. Li, H.M.; Li, L. Mean and extreme climate change on the Qinghai-Tibetan Plateau with a $2{ }^{\circ} \mathrm{C}$ global warming. Prog. Clim. Chang. Res. 2015, 11, 157-164.

48. Yang, S.Q.; Yang, X.B.; You, Y.; Qiu, Y.S.; Wang, L. Projection for climate change of the eastern Qinghai-Tibetan Plateau based on the statistical downscaling method. J. Southwest Univ. Nat. Sci. Ed. 2013, 35, 147-156.

49. Hu, Q.; Jiang, D.B.; Fan, G.Z. Climate change projection on the Tibetan Plateau: Results of CMIP5 models. Atmos. Sci. 2015, 39, 260-270.

50. Yin, Y.H.; Wu, S.H.; Zhao, D.S.; Zheng, D.; Pan, T. Modeled effects of climate change on actual evapotranspiration in different eco-geographical regions in the Tibetan Plateau. J. Geogr. Sci. 2013, 23, 195-207. [CrossRef]

51. Chen, D.L.; Xu, B.Q.; Yao, T.D.; Guo, Z.T.; Cui, P.; Chen, F.H.; Zhang, R.H.; Zhang, X.Z.; Zhang, Y.L.; Fan, J.; et al. Assessment of past, present and future environmental changes on the Tibetan Plateau. Chin. Sci. Bull. 2015, 60, 3025-3035.

52. Yuan, Q.Z.; Wu, S.H.; Dai, E.F.; Zhao, D.S.; Zhang, X.R.; Ren, P. Spatio-temporal variation of the wet-dry conditions from 1961 to 2015 in China. Sci. China Earth Sci. 2017, 60, 2041-2050. [CrossRef]

53. Lü, X.R.; Lü, X.Y. Climate tendency analysis of warming and drying in grassland of northeast Qingzang Plateau of China. Chin. Grassl. 2002, 24, 9-14.

54. Zhang, Y.L.; Qi, W.; Zhou, C.P.; Ding, M.J.; Liu, L.S.; Gao, J.G.; Bai, W.Q.; Wang, Z.F.; Zheng, D. Spatial and temporal variability in the net primary production (NPP) of alpine grassland on Tibetan Plateau from 1982 to 2009. Acta Geogr. Sin. 2013, 68, 1197-1211.

55. Melillo, J.M.; Mcguire, A.D.; Kicklighter, D.W.; Moore, B.; Vorosmarty, C.J.; Schloss, A.L. Global climate change and terrestrial net primary production. Nature 1993, 363, 234-240. [CrossRef]

56. Ganjurjav, H.; Gao, Q.Z.; Gornish, E.S.; Schwartz, M.W.; Liang, Y.; Cao, X.J.; Zhang, W.N.; Zhang, Y.; Li, W.H.; Wan, Y.F.; et al. Differential response of alpine steppe and alpine meadow to climate warming in the central Qinghai-Tibetan Plateau. Agric. For. Meteorol. 2016, 223, 233-240. [CrossRef]

57. Kato, T.; Tang, Y.H.; Gu, S.; Hirota, M.; Cui, X.Y.; Du, M.Y.; Li, Y.N.; Zhao, X.Q.; Oikawa, T. Seasonal patterns of gross primary production and ecosystem respiration in an alpine meadow ecosystem on the Qinghai-Tibetan Plateau. J. Geophys. Res. Atmos. 2004, 109, 1-9. [CrossRef] 
58. Kato, T.; Tang, Y.H.; Gu, S.; Hirota, M.; Du, M.Y.; Li, Y.N.; Zhao, X.Q. Temperature and biomass influences on interannual changes in $\mathrm{CO}_{2}$ exchange in an alpine meadow on the Qinghai-Tibetan Plateau. Glob. Chang. Biol. 2006, 12, 1285-1298. [CrossRef]

59. Ganjurjav, H.; Hu, G.Z.; Wan, Y.F.; Li, Y.; Danjiu, L.B.; Gao, Q.Z. Different responses of ecosystem carbon exchange to warming in three types of alpine grassland on the central Qinghai-Tibetan Plateau. Ecol. Evol. 2018, 8, 1507-1520. [CrossRef]

60. Wang, X.X.; Dong, S.K.; Gao, Q.Z.; Zhou, H.K.; Liu, S.L.; Su, X.K.; Li, Y.Y. Effects of short-term and long-term warming on soil nutrients, microbial biomass and enzyme activities in an alpine meadow on the Qinghai-Tibet Plateau of China. Soil Biol. Biochem. 2014, 76, 140-142. [CrossRef]

61. Xue, X.; Peng, F.; You, Q.G.; Xu, M.H.; Dong, S.Y. Belowground carbon responses to experimental warming regulated by soil moisture change in an alpine ecosystem of the Qinghai-Tibet Plateau. Ecol. Evol. 2015, 5, 4063-4078. [CrossRef]

62. Chen, N.; Zhang, Y.J.; Zhu, J.T.; Zu, J.X.; Huang, K.; Li, J.X.; Liu, Y.J.; Cong, N.; Tang, Z.; Wang, L.; et al. Temperature-mediated responses of carbon fluxes to precipitation variabilities in an alpine meadow ecosystem on the Tibetan Plateau. Ecol. Evol. 2019, 9, 9005-9017. [CrossRef] [PubMed]

63. Kang, X.M.; Yan, L.; Cui, L.J.; Zhang, X.D.; Hao, Y.B.; Wu, H.D.; Zhang, Y.; Li, W.; Zhang, K.R.; Yan, Z.Q.; et al. Reduced carbon dioxide sink and methane source under extreme drought condition in an alpine peatland. Sustainability 2018, 10, 4285. [CrossRef]

64. Zhu, J.T.; Zhang, Y.J.; Jiang, L. Experimental warming drives a seasonal shift of ecosystem carbon exchange in Tibetan alpine meadow. Agric. For. Meteorol. 2017, 233, 242-249. [CrossRef]

65. Guan, S.; An, N.; Zong, N.; He, Y.T.; Shi, P.L.; Zhang, J.J.; He, N.P. Climate warming impacts on soil organic carbon fractions and aggregate stability in a Tibetan alpine meadow. Soil Biol. Biochem. 2018, 116, 224-236. [CrossRef]

66. Li, Y.Y.; Dong, S.K.; Liu, S.L.; Zhou, H.K.; Gao, Q.Z.; Cao, G.M.; Wang, X.X.; Su, X.K.; Zhang, Y.; Tang, L.; et al. Seasonal changes of $\mathrm{CO}_{2}, \mathrm{CH}_{4}$ and $\mathrm{N}_{2} \mathrm{O}$ fluxes in different types of alpine grassland in the Qinghai-Tibetan Plateau of China. Soil Biol. Biochem. 2015, 80, 306-314. [CrossRef]

67. Cui, L.J.; Kang, X.M.; Li, W.; Hao, Y.B.; Zhang, Y.; Wang, J.Z.; Yan, L.; Zhang, X.D.; Zhang, M.Y.; Zhou, J.; et al. Rewetting decreases carbon emissions from the Zoige Alpine Peatland on the Tibetan Plateau. Sustainability 2017, 9, 948. [CrossRef]

68. Mccarthy, J.F. Carbon fluxes in soil: Long-term sequestration in deeper soil horizons. J. Geogr. Sci. 2005, 15, 149-154. [CrossRef]

69. Peng, F.; Xue, X.; You, Q.G.; Zhou, X.H.; Wang, T. Warming effects on carbon release in a permafrost area of Qinghai-Tibet Plateau. Environ. Earth Sci. 2015, 73, 57-66. [CrossRef]

70. Peng, F.; You, Q.G.; Xu, M.H.; Guo, J.; Wang, T.; Xue, X. Effects of warming and clipping on ecosystem carbon fluxes across two hydrologically contrasting years in an alpine meadow of the Qinghai-Tibet Plateau. PLoS ONE. 2014, 9, e109319. [CrossRef]

71. Fu, G.; Zhang, X.Z.; Zhang, Y.J.; Shi, P.L.; Li, Y.L.; Zhou, Y.T.; Yang, P.W.; Shen, Z.X. Experimental warming does not enhance gross primary production and above-ground biomass in the alpine meadow of Tibet. J. Appl. Remote Sens. 2013, 7, 6451-6465. [CrossRef]

72. Chen, J.; Luo, Y.Q.; Xia, J.Y.; Shi, Z.; Jiang, L.F.; Niu, S.L.; Zhou, X.H.; Cao, J.J. Differential responses of ecosystem respiration components to experimental warming in a meadow grassland on the Tibetan Plateau. Agric. For. Meteorol. 2016, 220, 21-29. [CrossRef]

73. Li, J.; He, N.P.; Xu, L.; Chai, H.; Liu, Y.; Wang, D.L.; Wang, L.; Wei, X.H.; Xue, J.Y.; Wen, X.F.; et al. Asymmetric responses of soil heterotrophic respiration to rising and decreasing temperatures. Soil Biol. Biochem. 2017, 106, 18-27. [CrossRef]

74. Ma, W.W.; Alhassan, A.R.M.; Wang, Y.S.; Li, G.; Wang, H.; Zhao, J.M. Greenhouse gas emissions as influenced by wetland vegetation degradation along a moisture gradient on the eastern Qinghai-Tibet Plateau of North-West China. Nutr. Cycl. Agroecosyst. 2018, 112, 335-354. [CrossRef]

75. Easterling, D.R.; Meehl, G.A.; Parmesan, C.; Changnon, S.A.; Karl, T.R.; Mearns, L.O. Climate extremes: Observations, modeling, and impacts. Science 2000, 289, 2068-2074. [CrossRef]

76. Reichstein, M.; Bahn, M.; Ciais, P.; Frank, D.; Mahecha, M.D.; Seneviratne, S.I.; Zscheischler, J.; Beer, C.; Buchmann, N.; Frank, D.C.; et al. Climate extremes and the carbon cycle. Nature 2013, 500, 287-295. [CrossRef] [PubMed] 
77. Frank, D.; Reichstein, M.; Bahn, M.; Thonicke, K.; Frank, D.; Mahecha, M.D.; Smith, P.; Van der Velde, M.; Vicca, S.; Babst, F.; et al. Effects of climate extremes on the terrestrial carbon cycle: Concepts, processes and potential future impacts. Glob. Chang. Biol. 2015, 21, 2861-2880. [CrossRef]

78. Liu, D.; Wang, T.; Yang, T.; Yan, Z.J.; Liu, Y.W.; Zhao, Y.T.; Piao, S.L. Deciphering impacts of climate extremes on Tibetan grasslands in the last fifteen years. Sci. Bull. 2019, 64, 446-454. [CrossRef]

79. Jiang, L.; Chen, H.; Zhu, Q.A.; Yang, Y.Z.; Li, M.X.; Peng, C.H.; Zhu, D.; He, Y.X. Assessment of frozen ground organic carbon pool on the Qinghai-Tibet Plateau. J. Soil Sediment. 2019, 19, 128-139. [CrossRef]

80. Mu, C.C.; Li, L.L.; Wu, X.D.; Zhang, F.; Jia, L.; Zhao, Q.; Zhang, T.J. Greenhouse gas released from the deep permafrost in the northern Qinghai-Tibetan Plateau. Sci. Rep. 2018, 8, 4205. [CrossRef]

81. Chen, N.; Zhu, J.T.; Zhang, Y.J.; Liu, Y.J.; Li, J.X.; Zu, J.X.; Huang, K. Nonlinear response of ecosystem respiration to multiple levels of temperature increases. Ecol. Evol. 2019, 9, 925-937. [CrossRef]

82. Chen, Z.Q.; Shao, Q.Q.; Liu, J.Y.; Wang, J.B. Analysis of net primary productivity of terrestrial vegetation on the Qinghai-Tibet Plateau, based on MODIS remote sensing data. Sci. China Earth Sci. 2012, 55, 1306-1312. [CrossRef]

83. Wang, Y.X.; Zhao, S.D. Modelings of terrestrial carbon cycling. J. Appl. Ecol. 1998, 9, 100-106.

84. Mao, L.X.; Sun, Y.L.; Yan, X.D. Modeling of carbon cycling in terrestrial ecosystem: A review. Chin. J. Appl. Ecol. 2006, 17, 2189-2195.

85. Parton, W.J.; Scurlock, J.M.O.; Ojima, D.S.; Gilmanov, T.G.; Scholes, R.J.; Schimel, D.S.; Kirchner, T.; Menaut, J.C.; Seastedt, T.; Moya, E.G.; et al. Observations and modeling of biomass and soil organic matter dynamics for the grassland biome worldwide. Glob. Biogeochem. 1993, 7, 785-809. [CrossRef]

86. Xu, X.F.; Tian, H.Q.; Wan, S.Q. Climate warming impacts on carbon cycling in terrestrial ecosystems. J. Plant Ecol. 2007, 31, 175-188.

87. Zhao, J.C.; Qiao, F.L.; Song, Z.Y.; Bao, Y. Simulation and comparison of terrestrial carbon cycle with CLM3.5-DGVM. Adv. Mar. Sci. 2011, 29, 253-264.

88. Dai, E.F.; Huang, Y.; Wu, Z.; Zhao, D.S. Analysis of spatio-temporal features of a carbon source/sink and its relationship to climatic factors in the Inner Mongolia grassland ecosystem. J. Geogr. Sci. 2016, 26, $297-312$. [CrossRef]

89. Potter, C.S.; Klooster, S.; Brooks, V. Interannual variability in terrestrial net primary production: Exploration of trends and controls on regional to global scales. Ecosystems 1999, 2, 36-48. [CrossRef]

90. Pei, Z.Y.; Zhou, C.P.; Ouyang, H.; Yang, W.B. A carbon budget of alpine steppe area in the Tibetan Plateau. Geogr. Res. 2010, 29, 102-110.

91. Zhou, X.F.; Yu, F.; Cao, G.Z.; Yang, W.S.; Zhou, Y. Spatiotemporal features of carbon source-sink and its relationship with climate factors in Qinghai-Tibet Plateau grassland ecosystem during 2001-2015. Res. Soil Water Conserv. 2019, 26, 76-81.

92. Yao, Y.T.; Li, Z.J.; Wang, T.; Chen, A.P.; Wang, X.H.; Du, M.Y.; Jia, G.S.; Li, Y.N.; Li, H.Q.; Luo, W.J.; et al. A new estimation of China's net ecosystem productivity based on eddy covariance measurements and a model tree ensemble approach. Agric. For. Meteorol. 2018, 253, 84-93. [CrossRef]

93. Running, S.W.; Hunt, E.R. Generalization of a forest ecosystem process model for other biomes, BIOME-BGC, and an application for global-scale models. Scaling Physiol. Process. 1993, 141-158.

94. Kimball, J.S.; Thornton, P.E.; White, M.A.; Running, S.W. Simulating forest productivity and surface-atmosphere carbon exchange in the BOREAS study region. Tree Physiol. 1997, 17, 589-599. [CrossRef] [PubMed]

95. Wang, X.F.; Ma, M.G.; Song, Y.; Tan, J.L.; Wang, H.B. Coupling of a biogeochemical model with a simultaneous heat and water model and its evaluation at an alpine meadow site. Environ. Earth Sci. 2014, 72, 4085-4096. [CrossRef]

96. Li, C.H.; Han, H.Y.; Fan, Y.P.; Cao, H.J.; Wang, Y.T.; Sun, H. NPP change and scenario simulation in Wudaoliang area of the Tibetan Plateau based on Biome-BGC model. Geogr. Sci. 2019, 39, 1330-1339.

97. Zhang, J.; Pan, X.L.; Gao, Z.Q.; Shi, Q.D.; Lv, G.H. Carbon uptake and change in net primary productivity of oasis-desert ecosystem in arid western China with remote sensing technique. J. Geogr. Sci. 2006, 16, 315-325. [CrossRef]

98. Li, D.; Huang, Y.; Wu, Q.; Ming, Z.; Jin, D.Y. Modeling dynamics of soil organic carbon in an alpine meadow ecosystem on Qinghai-Tibetan Plateau using the Century model. Acta Pratacultura Sin. 2010, 19, 160-168. 
99. Zhang, Y.Q.; Tang, Y.H.; Jiang, J.; Yang, Y.H. Characterizing the dynamics of soil organic carbon in grasslands on the Qinghai-Tibetan Plateau. Sci. China Ser. D Earth Sci. 2007, 50, 113-120. [CrossRef]

100. Bosch, A.; Schmidt, K.; He, J.S.; Doerfer, C.; Scholten, T. Potential $\mathrm{CO}_{2}$ emissions from defrosting permafrost soils of the Qinghai-Tibet Plateau under different scenarios of climate change in 2050 and 2070. Catena 2017, 149, 221-231. [CrossRef]

101. Yi, S.H.; Wang, X.Y.; Qin, Y.; Xiang, B.; Ding, Y.J. Responses of alpine grassland on Qinghai-Tibetan plateau to climate warming and permafrost degradation: A modeling perspective. Environ. Res. Lett. 2014, 9, 074014. [CrossRef]

102. Zhuang, Q.; He, J.; Lu, Y.; Ji, L.; Xiao, J.; Luo, T. Carbon dynamics of terrestrial ecosystems on the Tibetan Plateau during the 20th century: An analysis with a process-based biogeochemical model. Glob. Ecol. Biogeogr. 2010, 19, 649-662. [CrossRef]

103. McGuire, A.D.; Sitch, S.; Clein, J.S.; Dargaville, R.; Esser, G.; Foley, J.; Heimann, M.; Joos, F.; Kaplan, J.; Kicklighter, D.W.; et al. Carbon balance of the terrestrial biosphere in the Twentieth Century: Analyses of $\mathrm{CO}_{2}$, climate and land use effects with four process-based ecosystem models. Glob. Biogeochem. Cycles 2001, 15, 183-206. [CrossRef]

104. Zhao, Z.H.; Liu, G.H.; Mou, N.X.; Xie, Y.C.; Xu, Z.R.; Li, Y. Assessment of carbon storage and its influencing factors in Qinghai-Tibet Plateau. Sustainability 2018, 10, 1864. [CrossRef]

105. Xu, L.; Yu, G.R.; He, N.P. Increased soil organic carbon storage in Chinese terrestrial ecosystems from the 1980s to the 2010s. J. Geogr. Sci. 2019, 29, 49-66. [CrossRef]

106. Borrelli, P.; Robinson, D.A.; Fleischer, L.R.; Lugato, E.; Ballabio, C.; Alewell, C.; Meusburger, K.; Modugno, S.; Schutt, B.; Ferro, V.; et al. An assessment of the global impact of 21st century land use change on soil erosion. Nat. Commun. 2017, 8, 2013. [CrossRef] [PubMed]

107. Petrescu, A.M.R.; Lohila, A.; Tuovinen, J.P.; Baldocchi, D.D.; Desai, A.R.; Roulet, N.T.; Vesala, T.; Dolman, A.J.; Oechel, W.C.; Marcolla, B.; et al. The uncertain climate footprint of wetlands under human pressure. Proc. Natl. Acad. Sci. USA 2015, 112, 4594-4599. [CrossRef]

108. Du, M.Y.; Kawashima, S.; Yonemura, S.; Zhang, X.Z.; Chen, S.B. Mutual influence between human activities and climate change in the Tibetan Plateau during recent years. Glob. Planet Chang. 2004, 41, 241-249. [CrossRef]

109. Chen, H.; Yang, G.; Peng, C.H.; Zhang, Y.; Zhu, D.; Zhu, Q.A.; Hu, J.; Wang, M.; Zhan, W.; Zhu, E.X.; et al. The carbon stock of alpine peatlands on the Qinghai-Tibetan Plateau during the Holocene and their future fate. Quat. Sci. Rev. 2014, 95, 151-158. [CrossRef]

110. Zhou, G.Y.; Zhou, X.H.; He, Y.H.; Shao, J.J.; Hu, Z.H.; Liu, R.Q.; Zhou, H.M.; Hosseinibai, S. Grazing intensity significantly affects belowground carbon and nitrogen cycling in grassland ecosystems: A meta-analysis. Glob. Chang. Biol. 2017, 23, 1167-1179. [CrossRef]

111. Lu, X.Y.; Yan, Y.; Sun, J.; Zhang, X.K.; Chen, Y.C.; Wang, X.D.; Cheng, G.W. Carbon, nitrogen, and phosphorus storage in alpine grassland ecosystems of Tibet: Effects of grazing exclusion. Ecol. Evol. 2015, 5, 4492-4504. [CrossRef]

112. Li, G.; Zhang, Z.; Shi, L.L.; Zhou, Y.; Yang, M.; Cao, J.X.; Wu, S.H.; Lei, G.C. Effects of different grazing intensities on soil C, N, and P in an alpine meadow on the Qinghai-Tibetan Plateau, China. Int. J. Environ. Res. Public Health 2018, 15, 2584. [CrossRef] [PubMed]

113. Ma, W.M.; Ding, K.Y.; Li, Z.W. Comparison of soil carbon and nitrogen stocks at grazing-excluded and yak grazed alpine meadow sites in Qinghai-Tibetan Plateau, China. Ecol. Eng. 2016, 87, 203-211. [CrossRef]

114. Li, W.; Cao, W.X.; Wang, J.L.; Li, X.L.; Xu, C.L.; Shi, S.L. Effects of grazing regime on vegetation structure, productivity, soil quality, carbon and nitrogen storage of alpine meadow on the Qinghai-Tibetan Plateau. Ecol. Eng. 2017, 98, 123-133. [CrossRef]

115. Guo, N.; Wang, A.D.; Degen, A.A.; Deng, B.; Shang, Z.H.; Ding, L.M.; Long, R.J. Grazing exclusion increases soil $\mathrm{CO}_{2}$ emission during the growing season in alpine meadows on the Tibetan Plateau. Atmos. Environ. 2018, 174, 92-98. [CrossRef]

116. Ma, K.; Liu, J.G.; Balkovic, J.; Skalsky, R.; Azevedo, L.B.; Kraxner, F. Changes in soil organic carbon stocks of wetlands on China's Zoige plateau from 1980 to 2010. Ecol. Model. 2016, 327, 18-28. [CrossRef]

117. Shi, X.M.; Li, X.G.; Li, C.T.; Zhao, Y.; Shang, Z.H.; Ma, Q.F. Grazing exclusion decreases soil organic C storage at an alpine grassland of the Qinghai-Tibetan Plateau. Ecol. Eng. 2013, 57, 183-187. [CrossRef] 
118. Li, W.; Huang, H.Z.; Zhang, Z.N.; Wu, G.L. Effects of grazing on the soil properties and C and N storage in relation to biomass allocation in an alpine meadow. J. Soil Sci. Plant Nutr. 2011, 11, 27-39.

119. Moore, T.R.; Roulet, N.T.; Waddington, J.M. Uncertainty in predicting the effect of climatic change on the carbon cycling of Canadian peatlands. Clim. Chang. 1998, 40, 229-245. [CrossRef]

120. Erwin, K.L. Wetlands and global climate change: The role of wetland restoration in a changing world. Wetl. Ecol. Manag. 2009, 17, 71-84. [CrossRef]

121. Zhou, J.J.; Xiang, J.; Wang, L.Y.; Zhong, G.S.; Zhu, G.F.; Liu, C.F.; Huang, M.H.; Feng, W.; Li, Q.Q.; Xue, D.X.; et al. The impacts of groundwater chemistry on wetland vegetation distribution in the northern Qinghai-Tibet Plateau. Sustainability 2019, 11, 5022. [CrossRef]

122. Bai, J.H.; Ouyang, H.; Xiao, R.; Gao, J.Q.; Gao, H.F.; Cui, B.S.; Huang, L.B. Spatial variability of soil carbon, nitrogen, and phosphorus content and storage in an alpine wetland in the Qinghai-Tibet Plateau, China. Soil Res. 2010, 48, 730-736. [CrossRef]

123. Luan, J.W.; Cui, L.J.; Xiang, C.H.; Wu, J.H.; Song, H.T.; Ma, Q.F. Soil carbon stocks and quality across intact and degraded alpine wetlands in Zoige, east Qinghai-Tibet Plateau. Wetl. Ecol. Manag. 2014, 22, 427-438. [CrossRef]

124. Wu, X.W.; Cao, R.; Wei, X.; Xi, X.Q.; Shi, P.L.; Eisenhauer, N.; Sun, S.C. Soil drainage facilitates earthworm invasion and subsequent carbon loss from peatland soil. J. Appl. Ecol. 2017, 54, 1291-1300. [CrossRef]

125. Cao, R.; Chen, Y.; Wu, X.; Sun, S. The effect of drainage on $\mathrm{CO}_{2}, \mathrm{CH}_{4}$ and $\mathrm{N}_{2} \mathrm{O}$ emissions in the Zoige peatland: A 40-month in situ study. Mires Peat 2018, 21, 1-15.

126. Li, C.Y.; Huang, Y.L.; Guo, H.H.; Cui, L.J.; Li, W. Draining effects on recent accumulation rates of $\mathrm{C}$ and $\mathrm{N}$ in zoige alpine peatland in the Tibetan Plateau. Water 2018, 10, 576. [CrossRef]

127. Cao, R.; Xi, X.Q.; Yang, Y.H.S.; Wei, X.; Wu, X.W.; Sun, S.C. The effect of water table decline on soil $\mathrm{CO}_{2}$ emission of Zoige peatland on eastern Tibetan Plateau: A four-year in situ experimental drainage. Appl. Soil Ecol. 2017, 120, 55-61. [CrossRef]

128. Dorsch, P.; Palojarvi, A.; Mommertz, S. Overwinter greenhouse gas fluxes in two contrasting agricultural habitats. Nutr. Cycl. Agroecosyst. 2004, 70, 117-133. [CrossRef]

129. Wang, D.L.; Li, X.C.; Pan, D.F.; DE, K.J. The ecological significance and controlling of rodent outbreaks in the Qinghai-Tibetan grasslands. J. Southwest Univ. Natl. Nat. Sci. Ed. 2016, 42, 237-245.

130. Yu, C.; Jia, T.T.; Pang, X.P.; Guo, Z.G. Effects of plateau pika (ochotona curzoniae) disturbing soil carbon and nitrogen distribution in alpine meadow. Acta Pedol. Sin. 2016, 53, 768-778.

131. Ye, G.H.; Chu, B.; Zhou, R.; Zhang, F.Y.; Hua, X.Z.; Hua, R.; Wang, T.; Dong, K.C.; Hua, L.M. Relationship between plant functional group distribution and soil properties under the disturbance of plateau pika. Chin. J. Ecol. 2019, 38, 2382-2388.

132. Zeng, L.; Zhao, Y.L.; Peng, Y.X.; Yang, C.; Bai, S. Soil properties variety of alpine sandy grassland under perturbation of ochotona curzoniae. Grassl. Prataculture 2018, 30, 50-53. 